\title{
Effect of sward height during lactation on heifer and calf performance
}

\author{
B.M. PEACHEY and S.T. MORRIS \\ Institute of Veterinary, Animal and Biomedical Sciences, Massey University, \\ Private Bag 11 222, Palmerston North
}

\begin{abstract}
The study compared the performance of Hereford $x$ Friesian heifers and their calves managed on a Low (58 $\pm 0.5 \mathrm{~mm}$ sward height) (L) or High $(107 \pm 1.4 \mathrm{~mm}$ sward height $)(\mathrm{H})$ pasture cover from calf birth up to weaning at about 90 days over spring 1997. Milk production was measured at days 29 and 65 of lactation using the weigh-nurse-weigh technique. At day 29 the heifers on $\mathrm{L}$ had dropped by 0.20 condition score units compared with those on $\mathrm{H}$ which increased $(\mathrm{P}<0.001)$ condition score by 0.32 units; however, by the end of the trial there was no difference in score between the two treatment groups. Sward height significantly affected milk production at day $65(\mathrm{P}<0.05)$, the High treatment group producing $24 \%$ more milk than the Low (8.7 vs $7.0 \mathrm{~kg} / \mathrm{cow}$,). There was a corresponding difference $(\mathrm{P}<0.001)$ between $\mathrm{ADG}$ of the calves on the $\mathrm{L}(0.95 \mathrm{~kg} /$ day $)$ and the $\mathrm{H}$ $(1.24 \mathrm{~kg} /$ day $)$ treatments from day 65 till weaning. Sward height had little effect on heifer and calf during early lactation. This suggests that under adverse conditions farmers could restrict lactating heifers for the first 65 days of lactation, when they are at a condition score of 3.0 or better, without adversely affecting dam or calf performance. This has practical implications for the date of calving and for feed planning on farms where beef breeding cows are usually run in conjunction with a ewe flock.
\end{abstract}

Keywords: beef cattle, body condition score, calf growth, lactation, sward height

\section{Introduction}

Under New Zealand's seasonal pasture production system, early-spring feed demands of newly calved and lambed stock often exceeds pasture growth. The farmer may need to manipulate feed supply and demand by altering lambing or calving dates or by restricting pasture intake of one class of stock. Restricting intake of the suckling cow and calf during early lactation could release pasture for associated ewes and lambs, when lactation increases their demands (Rattray et al. 1987).
The once-bred heifer system of beef production commonly involves weaning calves early at about 90 days of age to allow the heifers to gain in liveweight and condition for slaughter at 30-36 months (Keane 1988). If a restriction in sward surface height during early lactation has little effect on cow and calf performance, this pasture can be used later in the season to ensure both heifer and calf reach optimum slaughter weight. Other alternatives are to give pasture to other classes of stock such as ewes and their lambs or 15month replacement heifers before mating.

It is well established in the UK that the height of the sward grazed by beef cows and their calves greatly affect their performance (Baker et al. 1981). However, during early lactation the lactating beef cow may be insensitive to sward height, as she can mobilise body reserves to supply milk to the calf (Lowman et al. 1979) without losing body condition.

The efficiency of pasture production and consumption influences the profitability of beef production systems. The plane of nutrition before calving has a large influence on calf performance (Hight 1968). However, little work has been done in New Zealand on the effect of pasture restriction on cow and calf performance from birth until weaning at approximately 90 days.

This study examines the effects of a high or low sward surface height on the performance of the lactating heifer and her calf from birth until weaning in spring 1997 in the Manawatu.

\section{Materials and methods}

Hereford $\times$ Friesian heifers were mated to either Angus or Charolais sires at a mean liveweight of $327 \pm 18 \mathrm{~kg}$. The heifers were then rotationally grazed until calving at 24 months of age. Their average pre-calving weight was $461 \pm 31 \mathrm{~kg}$ and mean condition score was 3.4 . After calving 40 heifers and their calves from an original mob of 128 were selected to be set stocked at either a Low (L) pasture cover (20 cows and calves) or at a High $(\mathrm{H})$ pasture (20 cows and calves) through to weaning at 94 days of age. The $\mathrm{H}$ group was managed so that they had ad lib. access to pasture; sward height did not fall below $90 \mathrm{~mm}$ at any time. Sward height for the L group was managed by allocating a reduced 
grazing area and adding sheep to control sward height so that it did not exceed $60 \mathrm{~mm}$ during the trial. Allocation to treatment was based on equal numbers of sex and breed of calf and on birth date of calf. Sward surface height was measured (50 readings each over the entire grazing area for each treatment) weekly using the HFRO sward stick (Barthram 1986). Data from two cows and calves from the L group were not included, as one calf died and another was accidentally weaned early.

To estimate milk production of the heifers, two weigh-nurse-weigh (WNW) measurements were taken at day 29 and 65 after parturition. The calf was removed from its dam at approximately 4 p.m. and was then weighed the next morning before being allowed to suckle. After the calf stopped suckling for one minute it was reweighed. Any faeces or urine passed by the calf during the suckling period was collected and weighed. Three cow-calf pairs were measured at any one time and three observers monitored the process to ensure any faeces and urine was collected. The difference between the pre-suckling and post-suckling calf weight (adjusted for faecal and urinary losses) was assumed to equal the weight of the milk consumed and the milk yield of the heifer.

\section{Statistical methods}

All analyses were performed using the Statistical Analysis System computer package (SAS 1985). Data relating to the performance of heifers and their calves were analysed using the general linear model (Proc GLM) procedure to test effects of calf sex, sire breed of calf and treatment. Calf birth date was fitted as a covariate in the calf liveweight analyses. Differences between group means were tested using the t-test (Snedecor \& Cochran 1980). Results were expressed in terms of least squares mean $\pm \mathrm{SEM}$.

\section{Results}

\section{Sward height}

Sward height was maintained at the targets of 50-60 $\mathrm{mm}$ for the $\mathrm{L}$ treatment group and greater than $90 \mathrm{~mm}$ for the $\mathrm{H}$ treatment group (Figure 1). Mean sward surface height was $58 \pm 5 \mathrm{~mm}$ for the L treatment group and $107 \pm 14 \mathrm{~mm}$ for the $\mathrm{H}$ treatment group.

\section{Effect of sward height on heifer dam performance}

Sire breed of calf had no effect on the performance of the heifers, nor were there any significant interactions between sire breed of calf and sward height found for heifer or calf performance. Therefore only sward height data are presented. The heifers on $\mathrm{L}$ decreased in condition score from calving until 29 days later whereas those on $\mathrm{H}$ increased $(\mathrm{P}<0.001)$ in condition score (Table 1). By day 65, cows on $\mathrm{H}$ produced $1.7 \mathrm{~kg}$ more milk than cows on $\mathrm{L}(\mathrm{P}<0.05)$ (Table 1). There were no differences in cow condition score at weaning. Differences in average liveweight after calving (day zero, D 0) between the two treatment groups were not significant.

\section{Effect of sward height on calf performance}

There was no effect of sward height on calf performance during lactation. From day 65 to weaning, however, sward height significantly $(\mathrm{P}<0.001)$ affected calf ADG (Table 2). There was no other effect of sward height on calf performance from birth to weaning. There were no significant interactions between sward height and sire breed of calf or sward height and sex of calf.

\section{Discussion}

Our finding that milk production was similar for both groups of heifers during the first month of lactation was consistent with other reports (Lowman et al. 1979; Pleasants \& Barton 1979). During early

Figure 1 Average weekly sward surface height for the High and Low treatments throughout the trial.

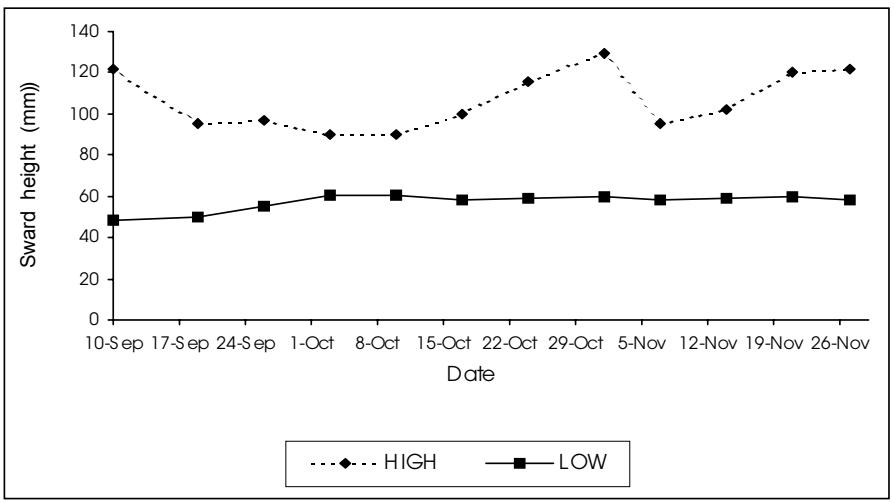

lactation cows are able to mobilise their body reserves without a decrease in milk production. Reduced milk production from the L group compared with $\mathrm{H}$ in late lactation agrees with the results of Wright \& Whyte (1989), who found that the response of calf liveweight gain to sward height was much greater in late lactation than early. Because sward height in early lactation had little effect on calf performance, farmers could if necessary restrict pasture intake for cows and calves over this period. This restriction would allow the farmer to divert the pasture to other classes of livestock or to save it for 
Table 1 Effect of a High or Low sward height on heifer dam performance from birth to weaning of calf (Least squares mean \pm SEM).

\begin{tabular}{|c|c|c|}
\hline & \multicolumn{2}{|c|}{------- Sward height --------- } \\
\hline & High & Low \\
\hline No. of animals & 20 & 18 \\
\hline Initial liveweight (D 0, kg) & $400.3 \pm 8.4$ & $411.3 \pm 9.1$ \\
\hline$C S^{1}(\mathrm{D} 0)$ & $3.10 \pm 0.05^{\mathrm{a}}$ & $3.35 \pm 0.05^{b}$ \\
\hline Lwt: Day 29 (kg) & $435.6 \pm 8.1$ & $432.5 \pm 9.0$ \\
\hline$S(D 29)$ & $3.42 \pm 0.07^{a}$ & $3.15 \pm 0.08^{b}$ \\
\hline wt: Day $65(\mathrm{~kg})$ & $459.6 \pm 9.2$ & $464.8 \pm 9.8$ \\
\hline CS (D 65) & $3.53 \pm 0.08$ & $3.58 \pm 0.08$ \\
\hline Lwt: Day 94 (kg) & $455.7 \pm 9.5$ & $458.1 \pm 10.8$ \\
\hline CS (D 94) & $3.52 \pm 0.07$ & $3.52 \pm 0.07$ \\
\hline Milk production d & $5.0 \pm 0.3$ & $4.8 \pm 0.3$ \\
\hline Milk production d & $8.7 \pm 0.4^{a}$ & $7.0 \pm 0.5^{b}$ \\
\hline \multicolumn{3}{|c|}{$\begin{array}{l}1 \text { Condition score of the heifers } \\
\text { a,b Means within treatment groups and within the same row with } \\
\text { superscripts that do not contain a common letter are significantly } \\
\text { different }(P<0.05) \text {. }\end{array}$} \\
\hline
\end{tabular}

Table 2 Effects of High or Low sward height on calf performance from birth to weaning (Least squares mean \pm SEM).

\begin{tabular}{|c|c|c|}
\hline & \multicolumn{2}{|c|}{-.--- Sward height } \\
\hline & High & Low \\
\hline No. of animals & 20 & 18 \\
\hline Initial liveweight (D $0, \mathrm{~kg})$ & $36.0 \pm 0.9$ & $35.6 \pm 1.0$ \\
\hline Lwt: Day $29^{1}(\mathrm{~kg})$ & $68.8 \pm 1.5$ & $70.96 \pm 1.4$ \\
\hline $\mathrm{ADG}^{2}(\mathrm{D} 0-29, \mathrm{~kg} / \mathrm{d})$ & $0.67 \pm 0.02$ & $0.64 \pm 0.02$ \\
\hline Lwt: Day $65^{1}(\mathrm{~kg})$ & $108.0 \pm 2.1$ & $112.7 \pm 2.3$ \\
\hline ADG (D 29-65, kg/d) & $1.08 \pm 0.05$ & $1.16 \pm 0.06$ \\
\hline Lwt: Day $94^{1}(\mathrm{~kg})$ & $146.3 \pm 2.2$ & $145.1 \pm 2.4$ \\
\hline ADG (D 65-94, kg/day) & $1.24 \pm 0.06^{a}$ & $0.95 \pm 0.06^{b}$ \\
\hline ADG (D 0-94, kg/day) & $1.19 \pm 0.02$ & $1.18 \pm 0.03$ \\
\hline
\end{tabular}

1 Weights were age-adjusted.

2 Average daily gains of the calves.

$a, b$ Means within treatment groups and within the same row with superscripts that do not contain a common letter are significantly different $(P<0.05)$.

later use. Beef cows and calves are often run in conjunction with ewes and lambs who would benefit from the increased pasture allowance in early spring, as would 15-month-old heifer replacements which are required to reach target liveweights in preparation for mating. Excess pasture not required by other classes of livestock over this period could be converted into supplementary feed such as hay or silage.

Overall there was no difference in performance of the two trial groups for both calf and heifer performance up to weaning, which suggests that maintaining a sward height of 50-60 $\mathrm{mm}$ will have no effect on the animals. However, it must be noted that these animals were destined for slaughter in the once-bred heifer beef production system and were weaned early at approximately 90 days. During early lactation (up to 50-60 days) results suggest that the $\mathrm{L}$ heifers mobilised body reserves to provide milk for the calves. There was a large drop in milk production at 65 days; however, it was not sufficient to affect calf liveweight, although ADG of the calves in the Low group was significantly lower than those in the High from day 65 till weaning. We speculate that continuing to restrict sward height of the heifer and calf over a longer lactation length (120200 days) could decrease calf growth. This reflects the suckling calf's increasing reliance on herbage and decreasing reliance on milk with age (Le Du et al. 1976). The heifer, which may be continuing to provide milk for the calf could also decrease in condition over an extended lactation.

The effects on reproductive performance were not investigated in this experiment. It is well known that nutrition in early lactation has a large influence on the return to oestrus of the cow (Bellows \& Short 1993). Beef breeding cows are required to get back in-calf quickly to maintain a 365-day calving interval, which may not be possible if their pasture intake is restricted over the first two months of lactation. Therefore the effect of restricted sward height on cow reproduction needs to be researched before it is used as a management tool for beef breeding cows. The condition of the dam before calving should also be researched as it may influence her response to restricted sward intake during early lactation.

\section{Conclusion}

Restricting sward surface height to $50-60 \mathrm{~mm}$ for heifers and their calves from calving, to weaning at approximately 90 days resulted in no change in either heifer or calf performance. This suggests that the farmer may restrict pasture intake during early lactation for heifers that have been calved at a condition score of 3.0 or better, but the ramifications for reproductive performance are unknown. This has practical implications with regards to calving date and for feed planning.

\section{ACKNOWLEDGEMENTS}

B. Peachey was a recipient of a Helen Royle Scholarship.

\section{REFERENCES}

Baker, R.D.; Le Du, Y.L.P.; Alvarez, F. 1981. The herbage intake and performance of set-stocked suckler cows and calves. Grass and forage science 36: 201-210.

Barthram, G.T. 1986. Experimental techniques: the HFRO sward stick. pp. 29-30. In: Biennial report 1984-85, Hill Farming Research Organisation. Penicuik. 
Bellows, R.A.; Short, R.E. 1993. Reproductive losses in the beef industry. pp 109-133. In: Factors affecting calf crop. Fields M.J.; Sand, R.S. (ed.) CRC Press, Boca Raton, Fl.

Hight, G.K. 1968. Plane of nutrition effects in late pregnancy and during lactation on beef cows and their calves to weaning. New Zealand journal of agricultural research 11: 71-84.

Keane, M.G. 1988. Extra calves from once-calved heifers. Farm and food research 19: 12-15.

Le Du, Y.L.P.; Baker, R.D.; Barker, J.M. 1976. Milkfed calves. 3. The milk intake, herbage intake and performance of suckled calves. Journal of agricultural science 87: 205-211.

Lowman, B.G.; Edmonds, R.A.; Somerville, S.H.; Jolly, G.M. 1979. The effect of plane of nutrition in early lactation on the performance of beef cows. Animal production 29: 293-303.
Pleasants, A.B.; Barton, R.A. 1979. Post-calving nutrition of single-suckled Angus beef cows. New Zealand journal of agricultural research 22: 1-7.

Rattray, P.V.; Thompson, K.F.; Hawke, H.; Sumner, R.M.W. 1987. Pastures for sheep production. pp. 89-103. In: Feeding Livestock on Pasture. Nicol, A.M. (ed.) New Zealand Society of Animal Production, occasional publication no. 10.

SAS 1985. SAS User's guide, statistics, version 5 edition. SAS Institute Inc. Box 800, Cary, North Carolina, 27511-8000.

Snedecor, G.W.; Cochran, W.G. 1980. Statistical methods. $8^{\text {th }} e d$. Ames: Iowa State University Press.

Wright, I.A.; Whyte, T.K. 1989. Effects of sward surface height on the performance of continuously stocked spring-calving beef cows and their calves. Grass and forage science 44: 259-266. 